\title{
The Prospects and Challenges of Electronic Finance in Nigeria
}

\author{
Achebe, P. N. \\ Department of Electrical and Electronic Engineering, Chukwuemeka Odumegwu Ojukwu University, Uli
}

\begin{abstract}
The advance in electronic technologies is making impact in every aspect of human endeavour, including financial sector. With the ever increasing technology in enhancing financial security and providing financial inclusiveness, electronic finance (e-finance) has become a key factor for economic growth. The use of personal computer $(P C)$, mobile phone, ATM, PoS, and internet facilities for online financial transaction is becoming increasingly common in Nigeria. This paper examined the prospects and challenges of electronic finance in Nigeria. The study was carried out using questionnaire randomly distributed to 60 respondents. Data obtained was analysed using statistical methods -frequency distributions tables and charts. The findings show that appreciable number of the respondents indicated high level of trust on e-payment system and also agree that e-finance system is very fast and convenient. However, reasonable number of the respondents disagree that network is always available or reliable.It was recommended that the government, telecommunication companies, and financial institutions corporate to ensure that network services are made available and reliable. The power supply system should be improved. The government should ensure that price of the PC (especially laptop) is reduced so more people can own computers at home. Finally, the growth of e-finance should be sustained with better policies. This will consequently bring about increasing financial inclusiveness.
\end{abstract}

Keywords - ATM, e-finance, mobile phone, PC, PoS

\section{INTRODUCTION}

Electronic finance (e-finance) is the use of such technologies like computers, mobile phones, Automated Teller Machines (ATMs), and Point of Sales (PoS) terminals including internet to carry out financial services and transactions. This paper seeks to assess the impact of these technologies in the Nigeria society with respect to perception and usage amongst customers of financial institutions.

With advancing and ever emerging sophisticated electronic devices for doing business including money transfer (or payment), there has been ease in financial transactions performed across the world. This easefulness includes time, safety, flexibility, accessibility, and comfort. The Nigeria society like other developing countries is fast growing its economy with these electronic technologies to enhance cash flow in the society, improve security, and create job opportunities.

In the Nigeria economy today, making payment for goods and services, and banking -deposit or withdrawal, airtime "top-up" can be done with electronic devices and internet. With the increasing growth in network coverage and access to internet provided by the telecommunication companies in Nigeria, different communities in the country regardless of the remoteness of the place, are gradually being connected. This has brought unprecedented growth and acceptability of e-finance in Nigeria. Also, the increase in e-finance can be attributed to the rate at which access to mobile phones with various banking and online transaction application are readily available today in Nigeria.

The Nigeria banking industry is becoming more robust and sophisticated. The banks now provide online banking platforms (applications) and codes for their customers to carry out their financial transactions with comfort. Also, the increasing rate and popularity of PoS terminals provided by mobile money merchants to every city, almost all towns and villages in Nigeria, has made e-finance a strategy for Nigerian economic growth and financial inclusiveness.

This paper examined the prospects and challenges of electronic finance in Nigeria. To achieve the aim of the paper, the remaining part of the study is divided into literature review, methodology, Analysis of results and discussion, conclusion and recommendation.

\section{LITERATURE REVIEW}

This section presents reports already established online and in published literature in the following subheadings. 


\section{A. Online Report}

According to online report by Kingston [1], the use of PoS for making financial transactions in Nigeria recorded 1.4 trillion naira in 2017. The report stated that "Nigerians are now more than ever using less cash for transactions and are instead resorting to PoS payments." The report further stated that a data from Nigerian Inter-Bank Settlement System indicated that the transaction worth obtained from an estimated 155,462 active PoS terminals that were made available to retailers by mobile money merchants (MMM).

The PoS terminals was introduced in 2012 by the Central Bank of Nigeria (CBN) to promote cashless policy which aimed to improve payment system in Nigeria. Statistical report has it that between January and December of the year 2017, transactions valued 91.29 billion naira (lowest) and 167.58 billion naira (highest) were recorded from PoS terminals. Statistical analysis revealed that PoS transaction increased by $85.75 \%$ from 0.758 trillion recorded in 2016 with this payment system used 1.46 million times in 2017. Between 2016 and 2017, the value of electronic transactions rose by $62.3 \%$ which is a record of 339.42 billion naira to 550.75 billion [1].

According to online report by ProShare Markets [2], electronic payment channels in the Nigeria banking sector indicated that transactions valued at 32.48 trillion naira with a total volume of 457,226,406 were recorded in the first quarter (Q1) of 2018. The transactions were dominated by ATM. A total volume of 212, 370.853 was recorded by the ATM transactions valued at 1,568 billion naira.

\section{B. Published Article Report}

Yakub et al (2013) examined the economic models of various mobile-payment systems in Nigeria. The distinctiveness and adaptabilities of the models were studied. The study recommended the Operator-Centric model because it suit the Nigeria economy. However, Non-Bank Led model was suggested in place of OperatorCentric due to their resemblance.

Agwu and Carter (2014) studied the level of mobile banking and the problem associated with it. The study observed that mobile phone banking recorded more usage than internet banking and ATM service, however, the level of penetration or reach was higher for ATM.

Abubakar (2014) studied the effect of electronic banking on the growth of deposit money banks in Nigeria. The study measured electronic banking on the value of internet and mobile banking while total value of deposits and total assets deposit money in Nigeria were used to measure the growth. The study indicated that positive relationships existed between mobile banking and total deposits, and between internet banking and total assets. However, no meaningful relationship existed between internet banking and total deposits, and between mobile banking and total asset. It was then recommended that banks that want their deposit growth performance to improve should provide several products/services through mobile phones.

Kadiri (2014) examined the prospects and problems of Information Technology (IT) in the Nigeria banking industry. The study observed that IT had positive effective effect on the productivity, transactions, service delivery of bank. However, unreliable network affects performance.

Tumibi and Falayi (2013) investigated security of IT and e-banking in the Nigeria banking industry. The study observed that there was a variation in the level of trust that customers had in their banks with respect to IT security. It maintained that IT security remains a major issue to banking in Nigeria.

Luka and Frank (2012) studied the impacts of ICTs on banking industry. The findings obtained revealed that basic ICT infrastructure including ATMs are essential to bank operation. It however maintained that to stay competitive in emerging economy, an ICT solutions that is scalable, flexible and robust is important.

\section{Common Electronic Payment System}

The electronic points of doing transactions in Nigeria commonly use in the financial sector can be represented as shown in Fig. 1.

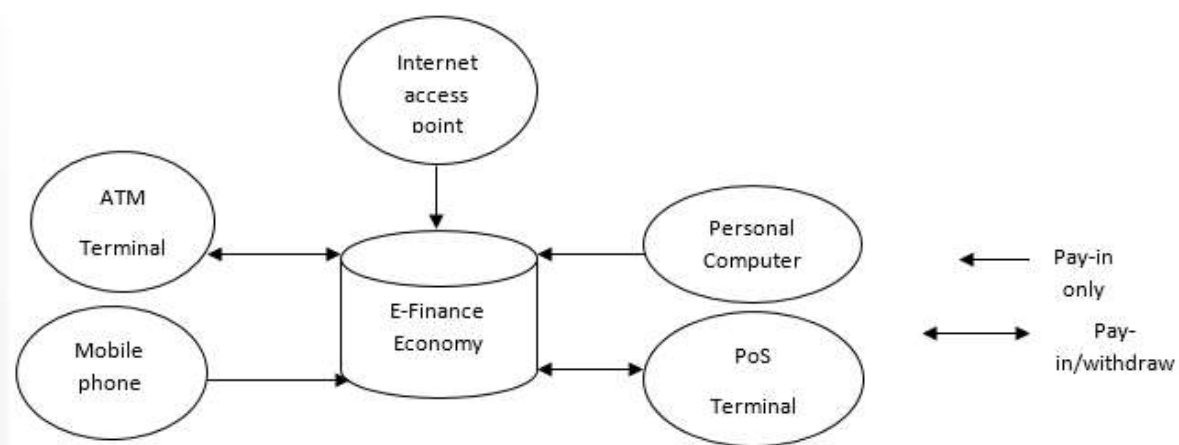

Fig.1 E-finance systems communicating with financial institution 
The communication between the e-finance systems and financial institution shown in Fig. 1, illustrates the kind of connection and transactions that can take place from each terminal. The financial transaction that a customer to a financial institution can do using mobile phone or personal computer with available network connection is payment (or deposit via online transfer) only. Using ATM or PoS, a customer can either make payment or withdraw.

\section{METHODOLOGY}

This study was carried out in South Eastern Nigerian City -Owerri, Imo State. The method of information or data gathering was based on the use of questionnaire. A total of 60 persons who are account holders in different banks were randomly sampled and given questionnaire. Statistical method using frequency tables and charts was adopted for data collection and analysis. The data was grouped as follows:

i. Gender of respondents

ii. Respondents' age

iii. Level of trust

iv. Respondents' perception on most often used electronic means of payment.

v. Perception of respondents on effectiveness of the electronic payment system based on network and other transaction related problems

The data gathered from respondents are presented in the distribution tables below. Tables I, II, III, IV, and V are the gender distribution, respondents' age distribution, level of trust distribution, most often used electronic means of payment, and effectiveness of the electronic payment system.

TABLE I GENDER DISTRIBUTION

\begin{tabular}{|l|l|}
\hline Gender & Frequency \\
\hline Male & 33 \\
\hline Female & 27 \\
\hline Total & 60 \\
\hline
\end{tabular}

TABLE 2 AGE OF RESPONDENTS

\begin{tabular}{|l|l|}
\hline Age & Frequency \\
\hline $16-20$ & 11 \\
\hline $21-25$ & 19 \\
\hline $26-30$ & 13 \\
\hline 30 and Above & 17 \\
\hline Total & 60 \\
\hline
\end{tabular}

TABLE 3 DISTRIBUTION OF LEVEL OF TRUST

\begin{tabular}{|l|l|}
\hline Rank & Frequency \\
\hline $0-20$ & 05 \\
\hline $21-40$ & 11 \\
\hline $41-60$ & 19 \\
\hline $61-80$ & 27 \\
\hline $81-100$ & 08 \\
\hline Total & 60 \\
\hline
\end{tabular}

TABLE 4 DISTRIBUTION OF MOST OFTEN USED E-PAYMENT SYSTEM

\begin{tabular}{|l|l|}
\hline E-Payment System & Frequency \\
\hline Personal Computer (PC) & 10 \\
\hline Mobile Phone & 23 \\
\hline ATM & 13 \\
\hline PoS & 14 \\
\hline Total & 60 \\
\hline
\end{tabular}

TABLE 5 EFFECTIVENESS OF THE ELECTRONIC PAYMENT SYSTEM

\begin{tabular}{|l|l|l|}
\hline Question & Agree & Disagree \\
\hline Transaction is very fast and convenient & 60 & 0 \\
\hline Network is available all the time & 29 & 31 \\
\hline Network is reliable all the time & 23 & 37 \\
\hline I have experienced financial fraud use e-payment system & 15 & 45 \\
\hline Lack of power supply hinders my transaction & 21 & 39 \\
\hline
\end{tabular}




\section{ANALYSIS OF RESULTS AND DISCUSSION}

A. Analysis of Result

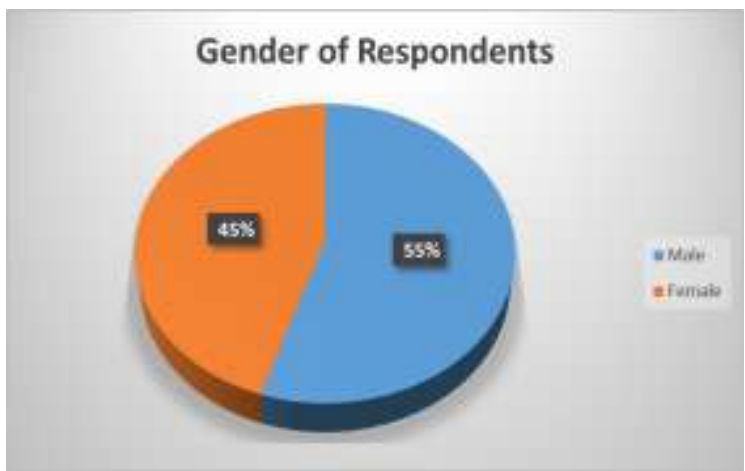

Fig. 2 Gender percentage

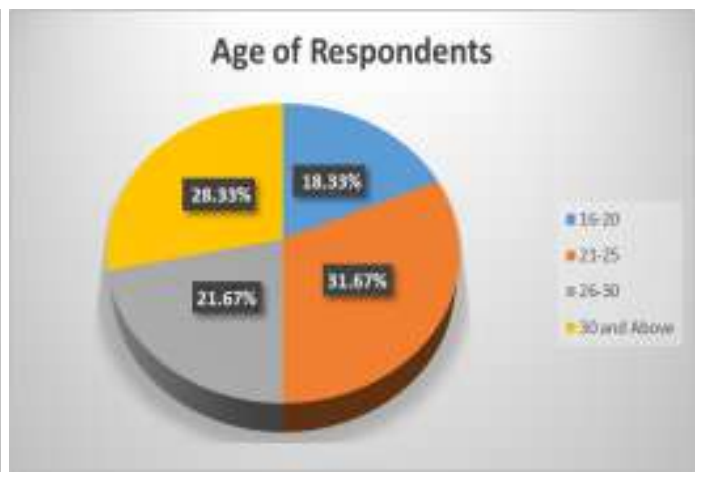

Fig. 3 Age percentage

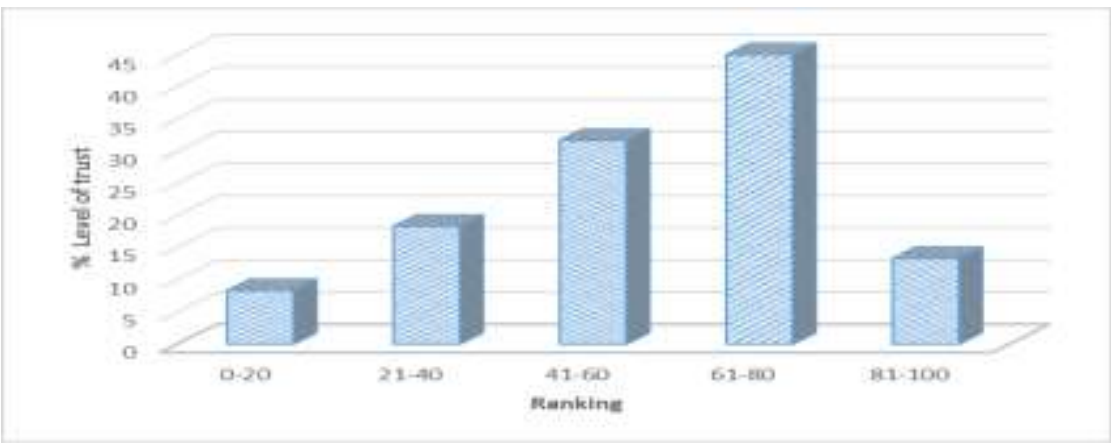

Fig. 4 Percentage Level of respondents' trust

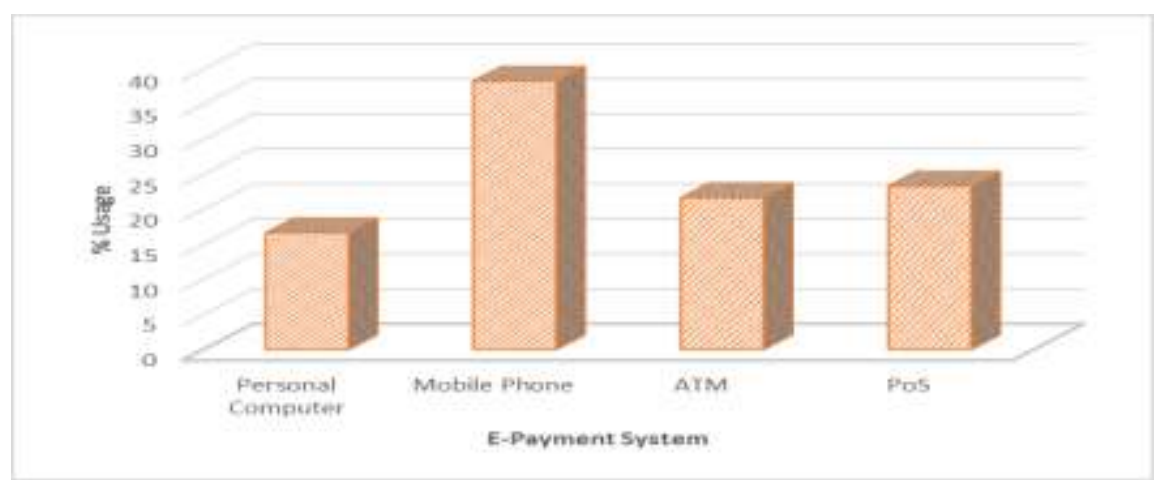

Fig. 5 Percentage most often used E- payment system 


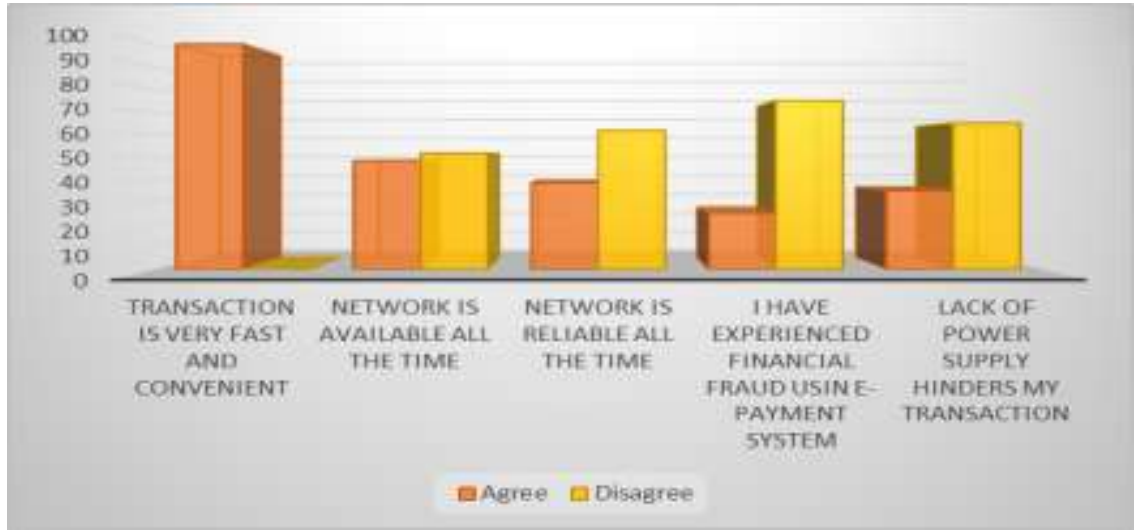

Fig. 6 Percentage effectiveness of e-payment system

\section{B. Discussion}

Figures 2 and 3 represent the respondents' gender and age. In Fig. 2, the pie chart shows that $55 \%$ of the respondents are male while $45 \%$ of the respondents are female. In terms of age population of the randomly sampled respondents, $18.33 \%$ are of age 16 to $20,31.67 \%$ are of age 21 to $25,21.67 \%$ are of age 26 to 30 , and $28.33 \%$ are of age 30 and above. It can be seen that the majority of the respondents are male and the customers within age 21 to 25 represent the age majority.

The level of trust the respondents have on the e-payment system is represented in Fig. 4. The responses for level of trust are expressed in percentage based on the following ranking. Very little level of trust: 0-20 (8.33\%), little level of trust: 21-40 (18.33\%), average level of trust: 41-60 (31.67\%), high level of trust: 61-80 (45\%), and very high level of trust: $81-100(13.33 \%)$. The chart shows that majority of the respondents have high level of trust on e-payment system.

The percentage of the most often used e-payment system by the respondents for carrying out financial transactions is shown in Fig. 5. Those who used personal computer (PC) most often are 16.67\%. People who used mobile phone most times are $38.33 \%$. Respondents using ATM most times are $21.67 \%$. Those who engaged the service of PoS most often are $23.33 \%$. It is obvious that majority of the respondents resort to using more of mobile phone than the rest due to the penetrating level of mobile phone in the society and the fact that it is more portable to carry around than others. Also, the increasing penetration of network provided by telecommunication companies can be attributed to this. The least use is the PC which probably is not own by majority of the respondents due to its cost.

In Fig. 6, the effectiveness of the e-payment system expressed in percentage is presented. It can be seen that all the respondents agree that the e-payment system is very fast and convenient (100\% agreement). When asked about the availability of the network for transaction, $48.33 \%$ agree that network is available all the time while $51.67 \%$ disagree. On the reliability of the network, $38.33 \%$ maintained that network is reliable all the time while $61.67 \%$ disagree. For those who have been defrauded through e-payment system, $25 \%$ claimed that they have experienced mobile banking fraud while $75 \%$ said they have not experienced such.

\section{CONCLUSION}

The paper has presented the prospects and challenges of e-finance in Nigeria. The study indicated that almost one fifth (1/5) of the sampled respondents show little level of trust in the e-finance in Nigeria while about one third (1/3) expressed average level of trust. In addition, the study revealed that the cause of this variation in the level of trust can be attributed to network issues arising from unreliable network, which often prevent them from doing transaction most at times from their different place of comfort and convenience. However, appreciable number of the respondents, representing about half of the sampled population, maintained high level of trust for e-finance. A number of the respondents (more than half) disagree that network is always available or reliable. Reasonable number, more than one third (1/3) agree that poor power supply affects e-payment system. With poor power supply system and unreliable network, people can lose trust in the use of their mobile phones and PCs in doing online financial transactions. Also, it will be very discouraging for a customer who ought to have used mobile phone or PC to do transaction from remote location to get to an ATM terminal and discover that it is out of service due to network problem. 


\section{RECOMMENDATIONS}

The following recommendations are made from the findings of the study:

i. There should be more synergy by the government, telecommunication companies, and financial institutions to ensure that network services are made available and reliable.

ii. The issue of poor power supply should be urgently addressed to enable the populace use their mobile phones and PCs for e- finance purposes as often as possible.

iii. The government should ensure that price of the PC (especially laptop) is reduced so that more people can own computers at home.

iv. The situation whereby banks deduct money from people using their ATM with card from a different bank should be discontinued.

V. Finally, the growth of e-finance should be sustained with better policies. This will consequently bring about increasing financial inclusiveness.

\section{REFERENCES}

[1] Kingston, D-H, "PoS transaction in Nigeria hit N 1.4 trillion in 2017," BUSINESS INSIDER, 2018. Sourced: Thursday, November 22, 2018. www.pulse.ng.

[2] Mobile Money and Telcos , "Banking Sector Records 457.23m Volume of Transactions in Q1 2018 -NBS," ProShare MARKETS, 2018. Sourced: Thursday, November 22, 2018. www.proshareng.com/news/mobile\%20money\%20and\%20Telcos//Banking-SectorRecords-457.23m-Volume-of-Transaction-in-q1-2018---NBS/30017

[3] J.O. Yakub, H.T Bello, I.A. Adenuga, "Mobile Money Services in Nigeria: An inquiry of existing Models, ” International Journal of Economics and Management Sciences, Vol. 2, No. 9, pp 94-105, 2013

[4] E. M. Agwu and A-L. Carter, "Mobile Phone Banking In Nigeria: Benefits, Problems and Prospects," International Journal of Business and Commerce, Vol. 3, No. 6, pp 50-70, 2014

[5] A. Abubakar, "The Effects of Electronic Banking on Growth of Deposit Money Banks in Nigeria," European Journal of Business and Management, Vol.6, No.33, pp 79-89, 2014

[6] K. O. Kadiri, “The Prospects \& Problems of Information Technology in the Banking Industry in Nigeria," IOSR Journal of Computer Engineering (IOSR-JCE), Vol.16, No.5, PP 28-35, 2014

[7] S. Tunmibi and E. Falayi, "IT Security and E-Banking in Nigeria," Greener Journal of Internet, Information \& Communication System, Vol. 1 (3), pp. 061-065, 2013.

[8] M. K. Luka and I. A. Frank, "The Impacts of ICTs on Banks, A Case study of the Nigerian Banking Industry," (IJACSA) International Journal of Advanced Computer Science and Applications, Vol. 3, No. 9, pp 145-149, 2012 